\title{
Review of renal artery embolization for treatment of renal angiomyolipoma
}

\author{
Melvin Omodon ${ }^{1 *}$, Gloria Ayuba ${ }^{2}$ and Indravadan J. Patel ${ }^{3}$ \\ *Correspondence: mel2ng@yahoo.com

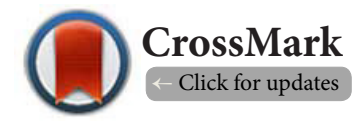 \\ ${ }^{1}$ Aultman Hospital, 2600 6th St SW, Canton, OH 44710, USA. \\ 2Beaumont Hospital- Dearborn MI 48124, USA. \\ ${ }^{3}$ Assistant Professor, Radiology, CWRU School of Medicine Cleveland, Ohio, USA.
}

\begin{abstract}
Renal angiomyolipoma (AML) is a benign renal neoplasm with the exception of the rare epithelioid variant. AML may be sporadic or may be associated with tuberous sclerosis complex or pulmonary lymphangioleiomyomatosis. Risk of hemorrhage is the concern for patients with AML. Renal artery embolization (RAE) is the treatment of choice for acute hemorrhage from angiomyolipoma, and also firstline prophylactic treatment for angiomyolipomas at risk of bleeding. This article reviews the prevalence of AML, factors associated with risk of hemorrhage, and the role of RAE in treatment of these patients.

Keywords: Angiomyolipoma, renal artery embolization, renal neoplasm, acute renal bleed, lymphangioleiomyomatosis, tuberous sclerosis, post-embolization syndrome
\end{abstract}

\section{Introduction}

Renal Angiomyolipoma (AML) is the most common benign tumor of the kidney with a prevalence of about 0.3 to $3 \%$ worldwide, with a significant higher prevalence in females than males [1]. It is a neoplasm composed of dysmorphic tortuous vascular tissue, smooth muscle and fat. AML may be associated with Tuberous sclerosis complex (TSC) or pulmonary lymphangioleiomyomatosis (LAM) or may occur sporadically. There is no histologic difference between sporadic AML and TSC-associated AML. The vascular tissues are prone to aneurysm formation and rupture. Most cases of AML are incidentally found on imaging. Approximately $10 \%$ of patients diagnosed with renal AML have tuberous sclerosis [2]. When symptomatic, AML typically presents as palpable flank mass, hematuria and flank pain.

Approximately 17 to 20 percent of patients presenting with spontaneous perinephric hemorrhage have AML $[3,4]$. $90 \%$ of AML cases are unilateral, solitary lesions usually seen in the sporadic AML. Multiple bilateral AML is seen in about $10 \%$ of the cases which are usually associated with TSC or LAM. TSC-associated AML is associated with loss of heterozygosity mutations of both TSC 1 and TSC2 genes compared to mutations of the TSC2 gene seen in the sporadic AML [5-7]. It is hypothesized that dysregulated mammalian target or rapamycin (mTOR) signaling increases tumor cell growth, proliferation, and metabolism thus promoting progression of TSC lesions.
Angiomyolipomas associated with TSC grows more rapidly, bleeds more frequently, and more likely involve bilateral kidneys compared to sporadic form [8-12]. TSC-associated AML typically present in younger patients, within the third decade of life compared to the sporadic form seen at about the fifth decade of life. TSC- associated AML is more likely to present with atypical features such as epithelioid component or epithelial cysts $[13,14]$. The epithelioid variant of renal AML is a rare aggressive and malignant disease with predominantly perivascular epithelial cells [15-17]. This variant typically displays nuclei atypia and relative paucity of adipose tissue.

Renal AML greater than $4 \mathrm{~cm}$ in diameter have a significant risk of hemorrhage [18]. Size greater than $4 \mathrm{~cm}$ approaches $100 \%$ sensitivity and $40 \%$ specificity to predict rupture. Threshold size for treatment of TSC-associated AML is $3 \mathrm{~cm}$, and for sporadic form is $4 \mathrm{~cm}$ [19]. Aneurysms greater than $5 \mathrm{~mm}$ in size are more predictive for rupture than tumor size. Other factors associated with increased risk of bleeding include pregnancy and use of estrogen containing contraceptive medication [20-22].

\section{Review \\ Imaging features}

Thin slice non-enhanced CT images are best suited to identify macroscopic fat (attenuation of between -30 to -100 HU) within the tumor. On imaging, a renal mass with macroscopic fat in an 
adult is the classical finding (Figures 1 and 2). Approximately $5 \%$ of AMLs may not have detectable fat on CT and may be missed by imaging. An observation of multiple AMLs on imaging usually indicate tuberous sclerosis. In large tumors greater than $4 \mathrm{~cm}$, hemorrhage may be seen. On CT angiography, multiple aneurismal vessels may be noted within the tumor and its periphery.
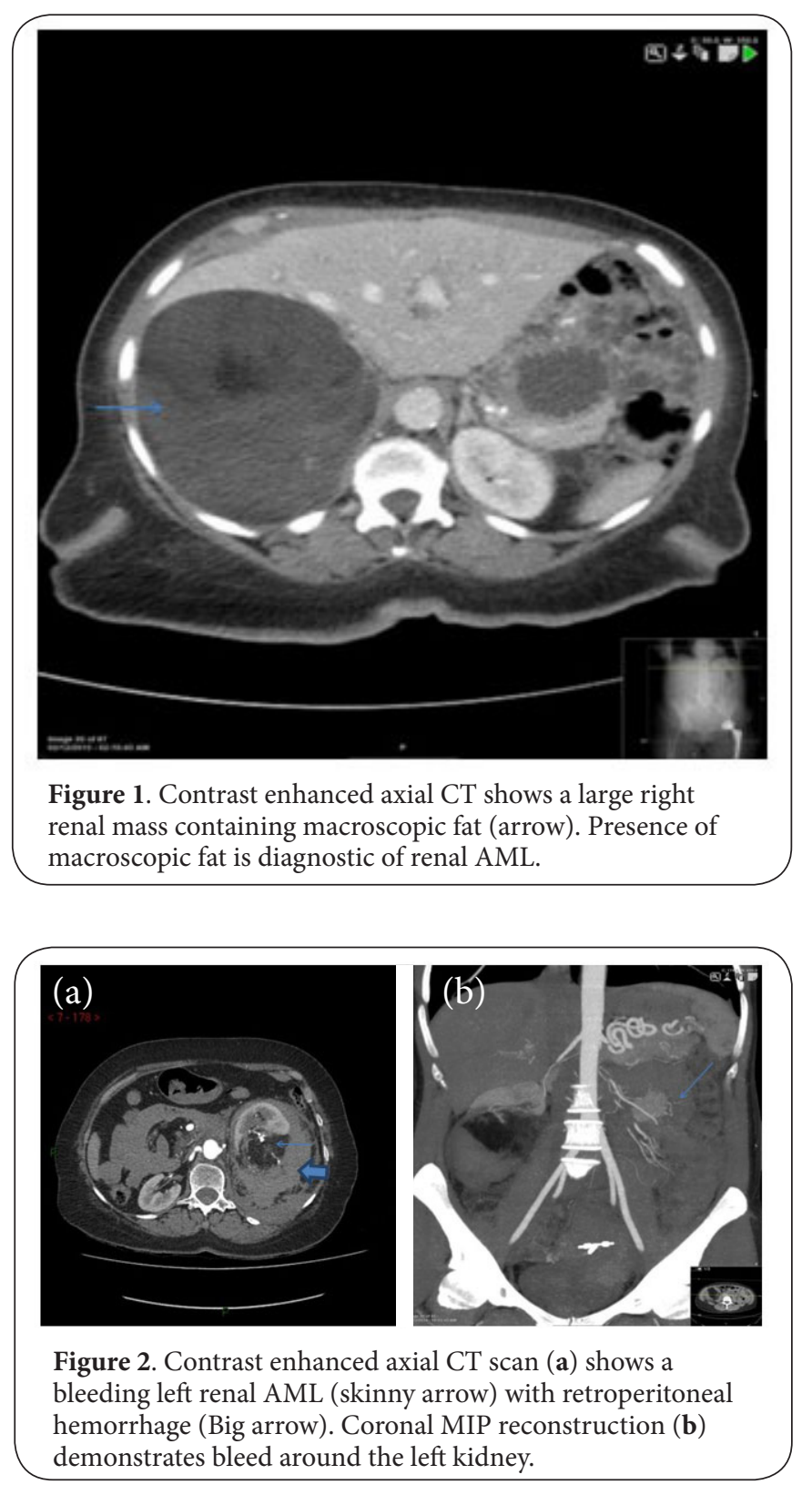

MRI signal characteristic is variable depending on the amounts of fat, smooth muscle and vascular tissue. Tumors that have a high relative fat content are hyperintense on $\mathrm{T} 1$ weighted images. There is typically loss of signal intensity on fat suppression images. A chemical-shift artifact may also be observed.
On the contrast enhanced T1 images there is significant enhancement of the vascular portion of this lesion. On gradient recalled echo (GRE) images, there is increased signal intensity with the in-phase images, and signal drop out with the outof-phase images depicting fat within the lesion (Figure 3).

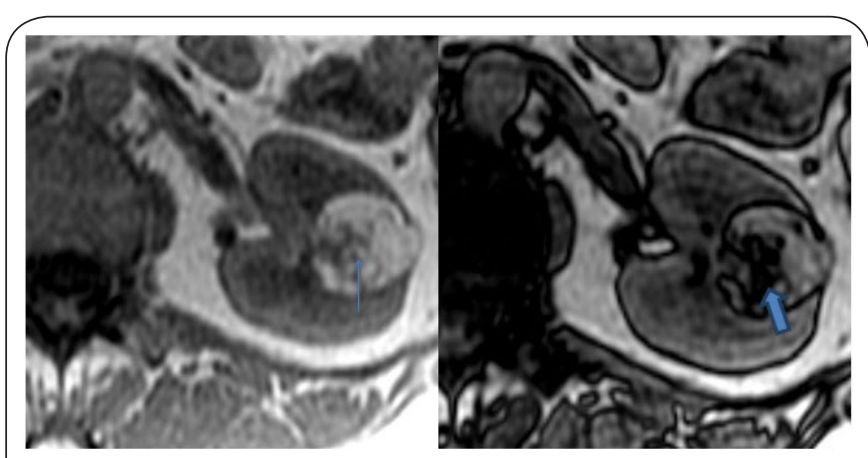

Figure 3. In-phase and out-of-phase images reveal a small left renal lesion with increased signal intensity on the in-phase images (thin arrow), and signal drop out on the out-of-phase images (thick arrow) depicting fat within the lesion.

On angiography, AMLs are a highly vascular tumor with multiple pseudoaneurysms. This gives the sunburst appearance in the capillary nephrogram phase. On the venous phase, there is an onion peel appearance of the peripheral vessels.

On ultrasound, renal AML is hyperechoic compared to normal renal parenchyma. Larger lesions may be heterogeneous and have varying vascularity (Figures 4 and $\mathbf{5}$ ). However AML is not reliably distinguished from other renal mass lesions such as renal cell carcinoma based on ultrasound findings.

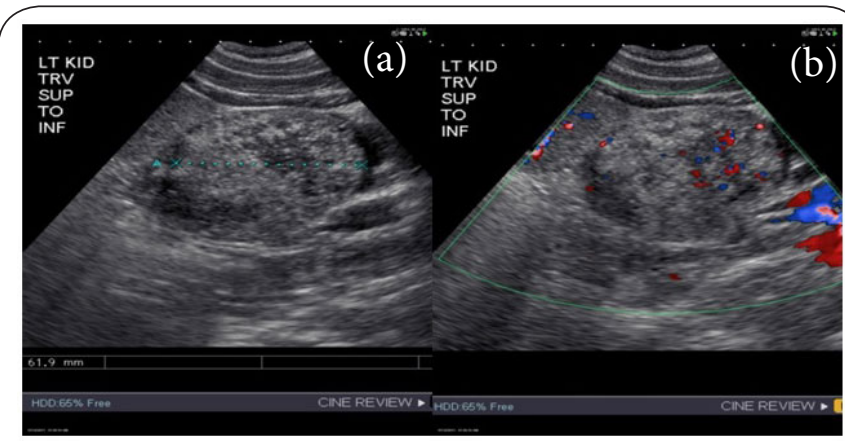

Figure 4. (a) Renal ultrasound showing a large heterogenous mass (indicated by the cursors) with hyperechoic and hypoechoic regions. (b) There is slightly increased vascularity on color doppler.

\section{Treatment}

Renal artery embolization (RAE) is the treatment of choice for acute hemorrhage from angiomyolipoma $[19,20,23]$. It is also the first-line prophylactic treatment for angiomyolipomas at risk of bleeding $[\mathbf{2 4 , 2 5 ]}$. Nephrectomy may be performed 


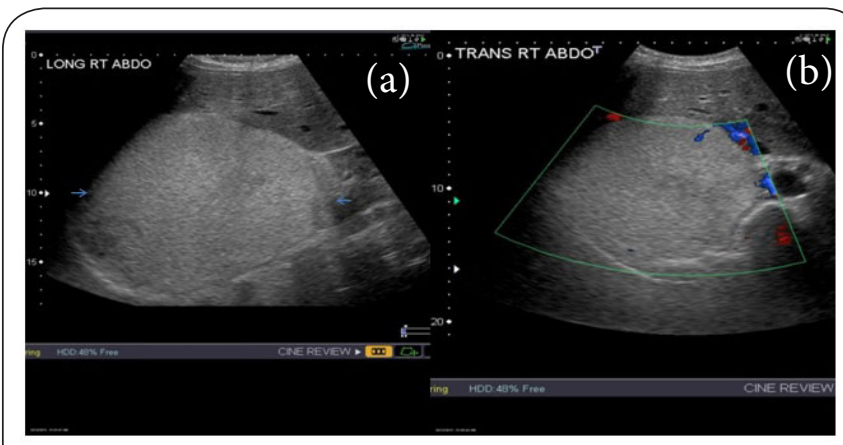

Figure 5. (a) Renal ultrasound showing a large hyperechoic mass (between arrows). (b) Mass does not reveal increase vascularity on color doppler.

if patients have refractory symptoms, complex renal artery anatomy, or in the rare instance of diagnostic uncertainty [26]. If surgery is performed, a nephron sparing approach may be followed in TSC-related AMLs, especially given propensity for recurrent lesions. Radiofrequency ablation, cryoablation and microwave ablation are other alternative treatment options. Mammalian target of rapamycin may be used to reduce the size of angiomyolipomas greater than $30 \mathrm{~mm}$ [19].

\section{Renal artery embolization}

Renal artery embolization was first developed in the 1970s and is used to treat conditions such as renal malignancies, renal aneurysms, and other vascular pathologies as well as complications from renal transplant $[27,28]$. Compared to surgical nephrectomy, RAE has less renal parenchymal volume loss, a shorter recovery time and generally fewer complications. However up to $5 \%$ of initial embolization may require a repeat embolization. In less than $7 \%$ of cases there is subsequent nephrectomy after $\operatorname{RAE}[\mathbf{8 , 2 9 , 3 0 - 3 5 ]}$. Lesions with a higher rate for subsequent re-embolization and potentially nephrectomy include larger lesions, hypervascular lesions, multiple lesions, bilateral lesions, and patients with tuberous sclerosis which have a higher tumor recurrence [8]. The use of larger particle size embolization agents have been shown to decrease the rate of repeat embolization [28].

The goal of renal artery embolization is selective devascularization of the AML with microparticles and coils to prevent growth of the mass or spontaneous aneurismal rupture, as well as to preserve normal renal parenchyma. In 90-100\% of cases after RAE, there is decrease in the AML volume by about $20-70 \%$ of the initial volume depending on the relative proportion of vascular and fatty components [8,29,30,32-41]. Reduction of volume is more noticeable in the vascular component compared to the fat component of AML.

\section{Preparation prior to procedure}

A thorough medical history is obtained including information concerning allergies. Recent laboratory evaluation of coagulation factors and renal function is obtained. Patient should have no oral intake for at least 6-8 hours prior to the procedure. Intravenous access is obtained. Some interventional radiologists prescribe prophylactic antibiotics to avoid subsequent infection within the infarcted areas. Prior to this procedure moderate sedation is given. General anesthesia is usually not required unless concentrated alcohol is used as a sclerosing agent, due to patient discomfort [42-44].

Before renal artery embolization, a detailed evaluation for variant anatomy of the renal arteries is recommended. This could be evaluated by CT, MRI or during angiography. A unilateral accessory renal artery is present in up to 30 percent of patients, and can be seen bilaterally in approximately $10 \%$ of patients. Knowledge of accessory renal arteries is needed to prevent incomplete embolization. The renal arteries arise from the abdominal aorta at the level of L1-L2. At the hilum of the kidney, the renal artery divides first into an anterior and a posterior branch which is subsequently divided into upper, middle, and lower segmental arteries. Segmental arteries give rise to the lobar arteries, which in turn give rise to the interlobar arteries after penetrating the renal parenchyma. Interlobar arteries give rise to the arcuate arteries which give rise to the interlobular arteries. Interlobular arteries become the afferent and efferent arterioles which cannot be distinguished by angiography.

\section{RAE procedure}

Vascular access is obtained commonly through a common femoral artery approach with an 18- or 19-gauge puncture needle via a modified Seldinger technique. A 4-6 French sized sheath is used. Axillary and brachial artery access, though rarely performed, may be necessary if there is iliac artery occlusion, significant tortuosity within the iliac artery, or other anatomic reasons [42].

Abdominal aortography is performed. It evaluates for renal ostial disease and offers information regarding possibility of accessory renal arteries. AML may receive vascular supply from other arteries such as adrenal, gonadal, and lumbar arteries. The main renal artery is selectively accessed with a 4-5 French size Cobra, visceral hook or Shepherd hook shaped catheter with coaxial microcatheter. For super-selective embolization, 3Fr micro catheters are used. This decreases the degree of renal infarction and morbidity [43]. Renal artery digital subtraction angiography (DSA) is performed to assess renal artery anatomy and to locate the AML(Figure 6). A guidewire is advanced to the artery supplying the AML (Figure 7). A catheter is advanced over the guidewire. Embolization particles or alcohol is then released at the target vessel. There should be stasis of contrast in the feeding artery upon completion of administration of the embolic agent. After embolization, DSA is performed to evaluate for proper treatment, assess for degree of renal parenchymal loss and assess for complications (Figure 8).

\section{Embolic agents}

The most commonly used embolic agents are absolute alco- 


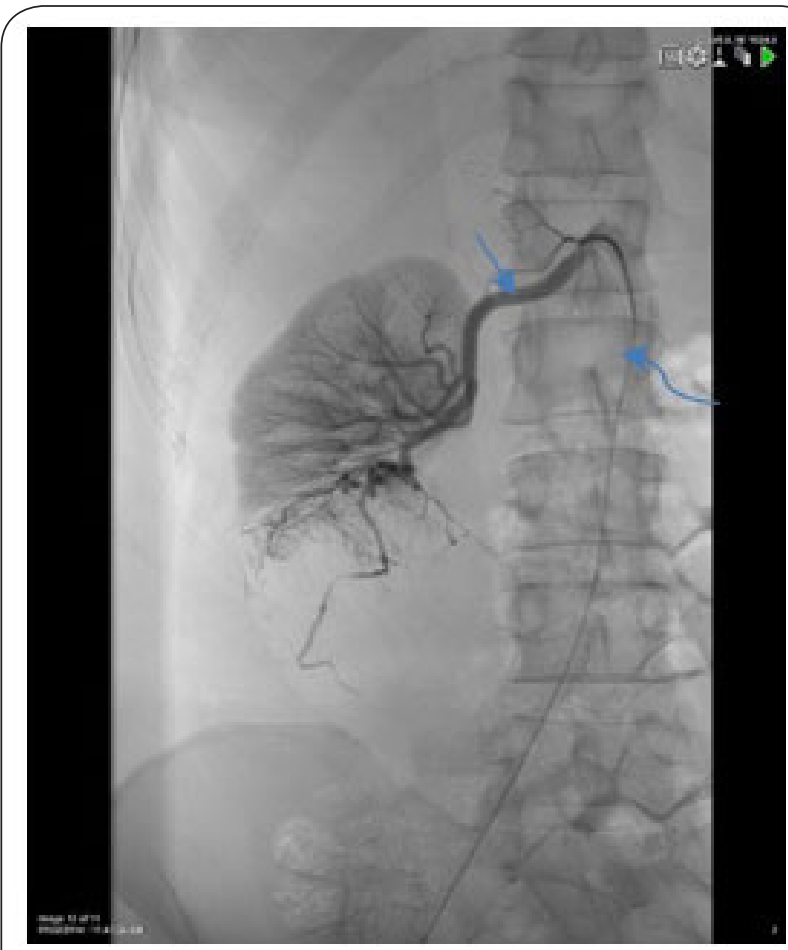

Figure 6. A right renal artery Digital subtraction angiogram (DSA) image shows selection of the right renal artery (straight arrow) with a 5 french selective catheter (curved arrow).

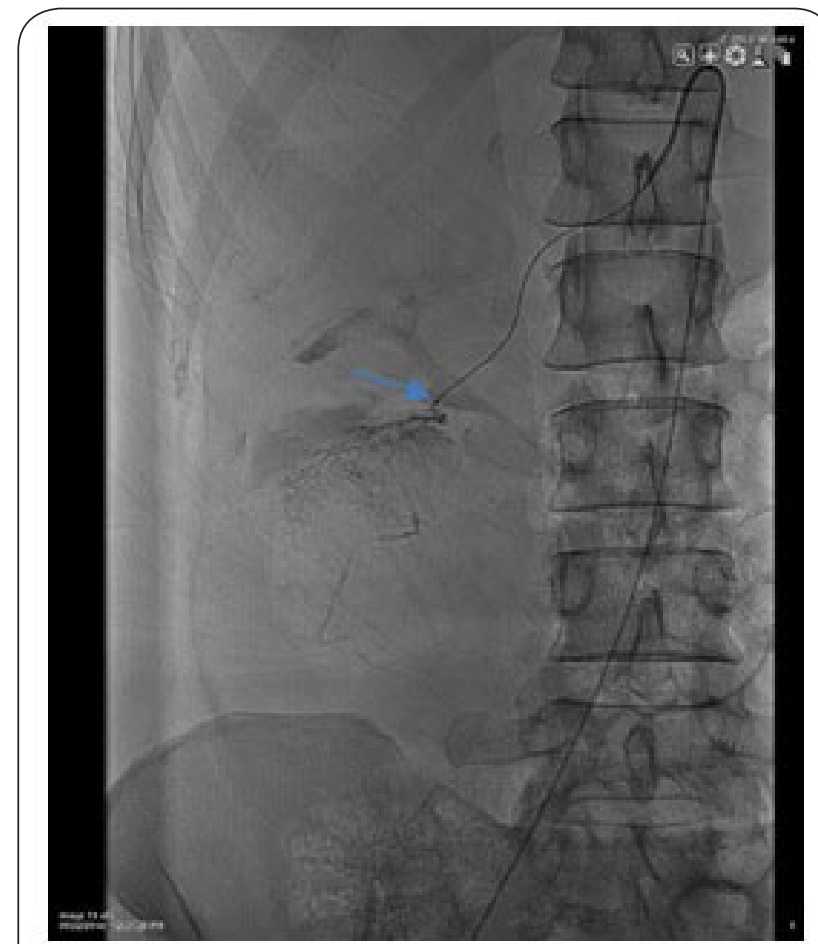

Figure 7. Subselective lower pole angiogram through a microcatheter (arrow). Subselective release of embolization material at the target artery perfusing the AML is performed.

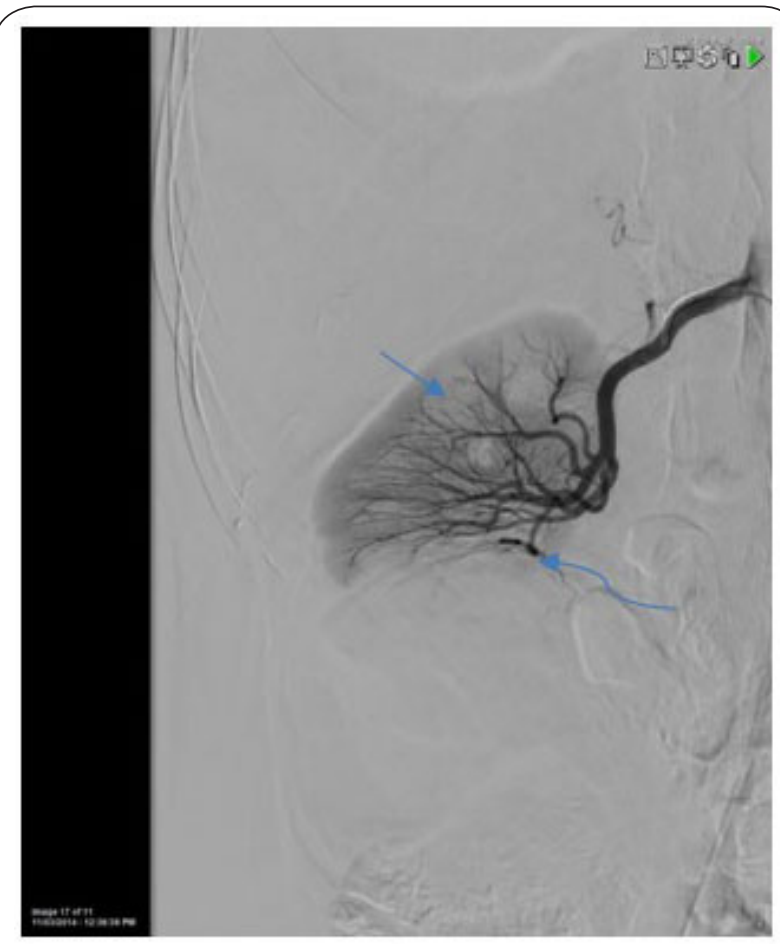

Figure 8. Post embolization renal angiogram shows little to no flow to renal AML (curved arrow) and preserved flow to the remaining normal renal parenchyma (straight arrow).

hol and microspheres. Absolute alcohol provides permanent occlusion at the arteriolar and capillary level distal to the level of collateral inflow. This subsequently causes necrosis of the tumor. There is a higher theoretical risk of nontarget embolization compared to microspheres due to reflux of alcohol from the vessels [45]. Therefore, an occlusion balloon may be advanced selectively to the renal arteries distal to the origin of the adrenal and ureteral branches to decrease this risk. The balloon remains inflated for several minutes after alcohol Injection into the renal artery.

Inert microparticles such as Trisacryl-gelatin microspheres (Embosphere ${ }^{T M}$, Guerbet, France) and Non-spherical polyvinyl alcohol particles, Ivalon (Ivalon ${ }^{\mathrm{TM}}$, Medsorb Dominicana, USA) also provide permanent distal occlusion of capillaries leading to tissue necrosis. Embospheres are typically the most common used microparticle for distal embolization of renal arteries. Embosphere can be calibrated in different sizes $(100-1,000 \mu \mathrm{m})$ to suit targeted vessels and hence produces a more consistent outcome [46]. A calibrated polyvinyl alcoholbased microsphere is also available (Contour $\mathrm{SE}^{\mathrm{TM}}$, Boston Scientific, USA; Bead Block ${ }^{\mathrm{TM}}$, Biocompatibles, UK).

Coils can also be used for renal artery embolization. They thrombose vessels by causing vascular stasis at the destination site. Once a vessel is coiled, further access cannot be obtained for retreatment. Therefore vessels distal to the lesion are first coiled before more proximal vessels which also 
preventsbleeding from retrograde collaterals.

\section{Contraindications}

Relative contraindications to renal artery embolization include a solitary kidney, or acute or chronic infection to the kidney due to concern for contrast induced renal damage. Patients with pre-existing renal disease are at a higher risk for contrast-induced nephrotoxicity. Adequate hydration is the most important factor in protecting renal function [47]. Radiation dose to the fetus is always of concern in pregnant patients [48-50]. Intravenous iodinated contrast is a US Food and Drug Administration Class B agent, and can be given in pregnancy [51]. Animal studies have not shown a risk to the fetus, and there is not sufficient data evaluating risk of contrast dose in pregnant women.

Microparticles are contraindicated in patients with arteriovenous fistula due to concern for particle migration causing pulmonary embolism. Coils may not be employed if there is concern for subsequent intervention at that arterial bed. When coils are used, subsequent intervention in the event of re-bleeding from collateral vessels may be compromised since the main feeding vessel has been occluded.

\section{Complications}

Renal artery embolization is generally associated with lower rate of complications compared to surgical procedures [27,52-55]. The most feared but rare complication is peri-procedural aneurysm rupture. Post-embolization syndrome comprising of abdominal pain, cramping, fever, nausea and vomiting may occur due to release of inflammatory modulators by the infracted tissues within 72 hours after embolization. This was seen in up to $62 \%$ of cases [56]. Larger lesions have a higher incidence of post embolization syndrome. Treatment is symptomatic relief with analgesia and IV fluids.

Non-target embolization is a less common complication which could lead to extensive infraction of the kidneys (Figure 9), adrenal glands, ureters, lower limbs, small and large intestines, and testicles. Damage to normal renal parenchyma can occur due to a lack of significant intrarenal collaterals.

Other complications include bleeding, infection, groin hematoma, arterial dissection, arterial spasm (Figure 10), contrast induced nephropathy, renal abscess (Figure 11), emphysematous pyelonephritis, and analphylaxis $[57,58]$.

\section{Conclusion}

Renal AML is a renal neoplasm which is benign with the exception of the rare epithelioid variant. AML may be sporadic or may be associated with tuberous sclerosis complex or pulmonary lymphangioleiomyomatosis. Patients with tuberous sclerosis have a higher rate for subsequent re-embolization, should be followed more closely clinically and with imaging and as warranted. Presence of macroscopic fat on imaging is classic for diagnosis. Aneurysm greater than $5 \mathrm{~mm}$ and tumor size greater than $4 \mathrm{~cm}$ are associated with a higher risk of rupture.

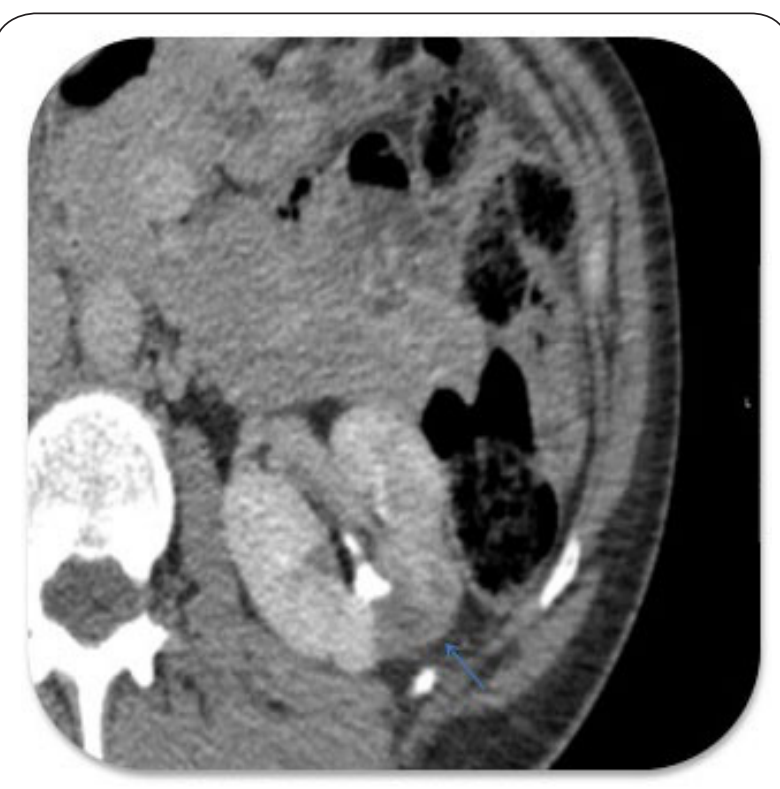

Figure 9. Contrast enhanced axial CT depicting a wedged shaped small left renal infarct caused by nontarget embolization of normal renal parenchyma.

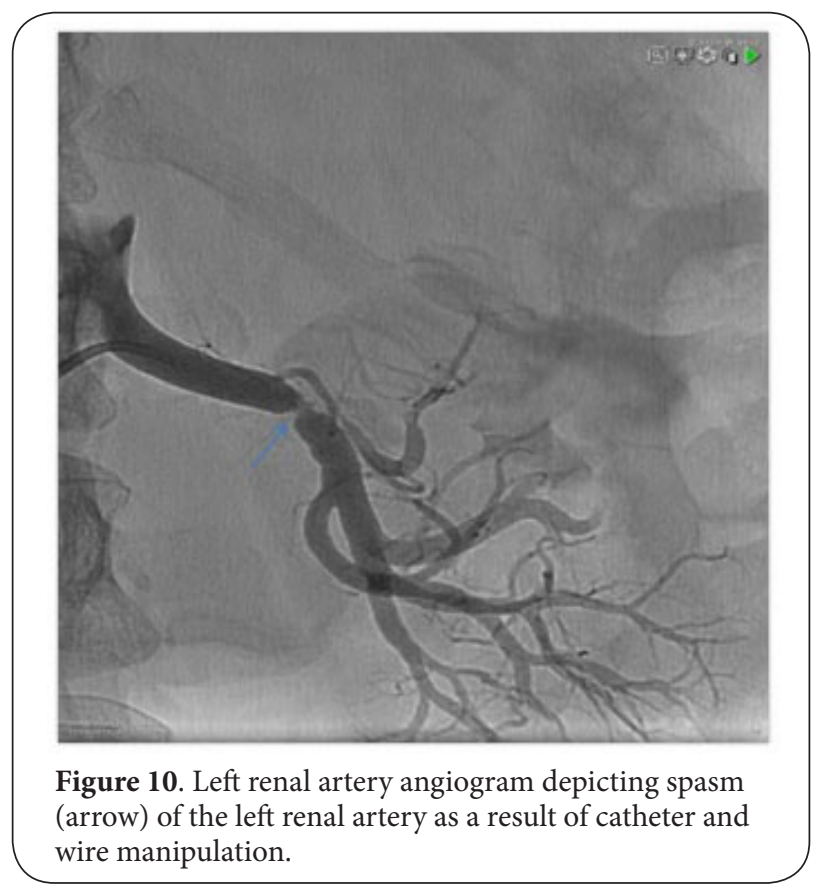

RAE is the treatment of choice for acute hemorrhage from angiomyolipoma, and also first-line prophylactic treatment for angiomyolipomas at risk of bleeding. Up to $5 \%$ of initial embolization may require a repeat embolization, and in a few cases post RAE nephrectomy may be necessary. Post embolization syndrome comprised of abdominal pain, cramping, fever, nausea and vomiting, is a relatively common complication especially in large tumors. Treatment is with symptom relief. 

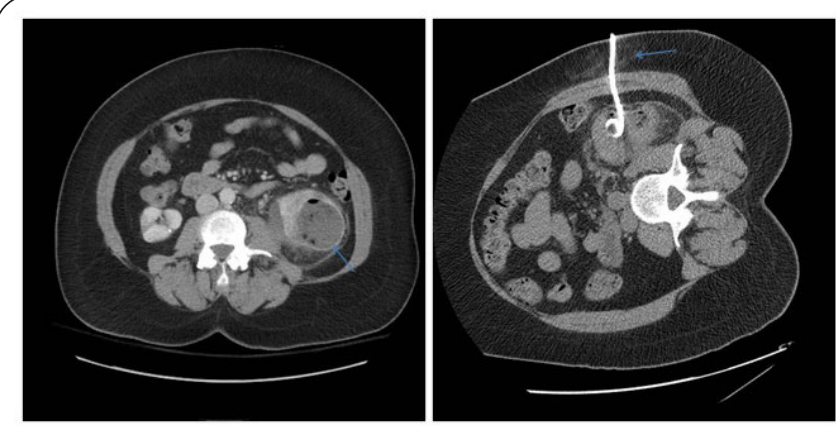

Figure 11. Contrast enhanced axial CT depicts a left renal abscess (arrow) in a patient who presented with a UTI post renal artery embolization for AML. This required CT guided drainage (arrow) (8B).

\section{Competing interests}

The authors declare that they have no competing interests.

\section{Authors' contributions}

\begin{tabular}{|l|c|c|c|}
\hline Authors' contributions & MO & GA & IJP \\
\hline Research concept and design & $\checkmark$ & -- & $\checkmark$ \\
\hline Collection and/or assembly of data & $\checkmark$ & $\checkmark$ & $\checkmark$ \\
\hline Data analysis and interpretation & -- & -- & -- \\
\hline Writing the article & $\checkmark$ & $\checkmark$ & $\checkmark$ \\
\hline Critical revision of the article & $\checkmark$ & $\checkmark$ & $\checkmark$ \\
\hline Final approval of article & $\checkmark$ & $\checkmark$ & $\checkmark$ \\
\hline Statistical analysis & -- & -- & -- \\
\hline
\end{tabular}

\section{Acknowledgement}

We thank Marlene Derrick for assisting in the literature review, providing articles and proof reading the paper.

\section{Publication history}

Editors: Andrew Zoltan Fenves, Massachusetts General Hospital, USA. Vito M. Campese, Keck School of Medicine, USA. John WM Yuen, Hong Kong Polytechnic University, China. EIC: Kevin R. Loughlin, Harvard Medical School, USA. Received: 05-Nov-2015 Final Revised: 30-Dec-2015 Accepted: 22-Jan-2016 Published: 02-Feb-2016

\section{References}

1. Fittschen A, Wendlik I, Oeztuerk S, Kratzer W, Akinli AS, Haenle MM and Graeter T. Prevalence of sporadic renal angiomyolipoma: a retrospective analysis of 61,389 in- and out-patients. Abdom Imaging. 2014; 39:100913. | Article | PubMed

2. Bissler JJ, Racadio J, Donnelly LF and Johnson ND. Reduction of postembolization syndrome after ablation of renal angiomyolipoma. Am J Kidney Dis. 2002; 39:966-71. I Article I PubMed

3. Zagoria RJ, Dyer RB, Assimos DG, Scharling ES and Quinn SF. Spontaneous perinephric hemorrhage: imaging and management. J Urol. 1991; 145:468-71. | Article I PubMed

4. Belville JS, Morgentaler A, Loughlin KR and Tumeh SS. Spontaneous perinephric and subcapsular renal hemorrhage: evaluation with $\mathrm{CT}, \mathrm{US}$, and angiography. Radiology. 1989; 172:733-8. I Article I PubMed

5. Henske EP, Neumann HP, Scheithauer BW, Herbst EW, Short MP and Kwiatkowski DJ. Loss of heterozygosity in the tuberous sclerosis (TSC2) region of chromosome band $16 \mathrm{p} 13$ occurs in sporadic as well as TSC- associated renal angiomyolipomas. Genes Chromosomes Cancer. 1995; 13:295-8. | Article | PubMed

6. Smolarek TA, Wessner LL, McCormack FX, Mylet JC, Menon AG and Henske EP. Evidence that lymphangiomyomatosis is caused by TSC2 mutations: chromosome $16 \mathrm{p} 13$ loss of heterozygosity in angiomyolipomas and lymph nodes from women with lymphangiomyomatosis. Am J Hum Genet. 1998; 62:810-5. | Article | PubMed Abstract | PubMed FullText

7. Dabora SL, Jozwiak S, Franz DN, Roberts PS, Nieto A, Chung J, Choy YS, Reeve MP, Thiele E, Egelhoff JC, Kasprzyk-Obara J, Domanska-Pakiela D and Kwiatkowski DJ. Mutational analysis in a cohort of 224 tuberous sclerosis patients indicates increased severity of TSC2, compared with TSC1, disease in multiple organs. Am J Hum Genet. 2001; 68:64-80. I Article | PubMed Abstract | PubMed FullText

8. Kothary N, Soulen MC, Clark TW, Wein AJ, Shlansky-Goldberg RD, Crino PB and Stavropoulos SW. Renal angiomyolipoma: long-term results after arterial embolization. J Vasc Interv Radiol. 2005; 16:45-50. | Article | PubMed

9. Halpenny D, Snow A, McNeill G and Torreggiani WC. The radiological diagnosis and treatment of renal angiomyolipoma-current status. Clin Radiol. 2010; 65:99-108. | Article | PubMed

10. Steiner MS, Goldman SM, Fishman EK and Marshall FF. The natural history of renal angiomyolipoma. J Urol. 1993; 150:1782-6. | Article | PubMed

11. Nelson CP and Sanda MG. Contemporary diagnosis and management of renal angiomyolipoma. J Urol. 2002; 168:1315-25. I Article I PubMed

12. Oesterling JE, Fishman EK, Goldman SM and Marshall FF. The management of renal angiomyolipoma. J Urol. 1986; 135:1121-4. | Article | PubMed

13. Eble JN, Amin MB and Young RH. Epithelioid angiomyolipoma of the kidney: a report of five cases with a prominent and diagnostically confusing epithelioid smooth muscle component. Am J Surg Pathol. 1997; 21:1123-30. | Article | PubMed

14. Aydin H, Magi-Galluzzi C, Lane BR, Sercia L, Lopez JI, Rini BI and Zhou M. Renal angiomyolipoma: clinicopathologic study of 194 cases with emphasis on the epithelioid histology and tuberous sclerosis association. Am J Surg Pathol. 2009; 33:289-97. | Article | PubMed

15. Amin MB. Epithelioid angiomyolipoma. In: Eble JN, Sauter G, Epstein JI, Sesterhenn IA (eds) WHO Classification of Tumours. Pathology and Genetics. Tumours of the Urinary System and Male Genital Organs. IARC Press: Lyon, France, 2004; 68-69.

16. Lai HY, Chen CK, Lee YH, Tsai PP, Chen JH and Shen WC. Multicentric aggressive angiomyolipomas: a rare form of PEComas. AJR Am J Roentgenol. 2006; 186:837-40. | Article | PubMed

17. Cui L, Zhang JG, Hu XY, Fang XM, Lerner A, Yao XJ and Zhu ZM. CT imaging and histopathological features of renal epithelioid angiomyolipomas. Clin Radiol. 2012; 67:e77-82. | Article | PubMed

18. Rimon U, Duvdevani M, Garniek A, Golan G, Bensaid P, Ramon J and Morag $B$. Large renal angiomyolipomas: digital subtraction angiographic grading and presentation with bleeding. Clin Radiol. 2006; 61:520-6. | Article I PubMed

19. Krueger DA and Northrup H. Tuberous sclerosis complex surveillance and management: recommendations of the 2012 International Tuberous Sclerosis Complex Consensus Conference. Pediatr Neurol. 2013; 49:255-65. | Article | PubMed Abstract | PubMed FullText

20. Rouviere O, Nivet H, Grenier N, Zini L and Lechevallier E. Kidney damage due to tuberous sclerosis complex: management recommendations. Diagn Interv Imaging. 2013; 94:225-37. | Article | PubMed

21. Yamakado K, Tanaka N, Nakagawa T, Kobayashi S, Yanagawa M and Takeda K. Renal angiomyolipoma: relationships between tumor size, aneurysm formation, and rupture. Radiology. 2002; 225:78-82. | Article I PubMed

22. Johnson SR, Cordier JF, Lazor R, Cottin V, Costabel U, Harari S, ReynaudGaubert M, Boehler A, Brauner M, Popper H, Bonetti F and Kingswood C. European Respiratory Society guidelines for the diagnosis and management of lymphangioleiomyomatosis. Eur Respir J. 2010; 35:1426. I Article I PubMed

23. Hamlin JA, Smith DC, Taylor FC, McKinney JM, Ruckle HC and Hadley HR. Renal angiomyolipomas: long-term follow-up of embolization for acute 
hemorrhage. Can Assoc Radiol J. 1997; 48:191-8. | Article | PubMed

24. Rouviere $\mathrm{O}$, Nivet $\mathrm{H}$, Grenier N, Zini L and Lechevallier E. Kidney damage due to tuberous sclerosis complex: management recommendations. Diagn Interv Imaging. 2013; 94:225-37. | Article | PubMed

25. Rouviere O, Nivet $\mathrm{H}$, Grenier N, Zini L and Lechevallier E. [Guidelines for the management of tuberous sclerosis complex renal disease]. Prog Urol. 2012; 22:367-79. | Article | PubMed

26. Faddegon $S$ and So A. Treatment of angiomyolipoma at a tertiary care centre: the decision between surgery and angioembolization. Can Urol Assoc J. 2011; 5:E138-41. | Article | PubMed Abstract | PubMed FullText

27. Turini D, Nicita G, Fiorelli C, Selli C and Villari N. Selective transcatheter arterial embolization of renal carcinoma: an original technique. J Urol. 1976; 116:419-21. | Article | PubMed

28. Villalta JD, Sorensen MD, Durack JC, Kerlan RK and Stoller ML. Selective arterial embolization of angiomyolipomas: a comparison of smaller and larger embolic agents. J Urol. 2011; 186:921-7. | Article | PubMed

29. Ramon J, Rimon U, Garniek A, Golan G, Bensaid P, Kitrey ND, Nadu A and Dotan ZA. Renal angiomyolipoma: long-term results following selective arterial embolization. Eur Urol. 2009; 55:1155-61. | Article | PubMed

30. Chan CK, Yu S, Yip S and Lee P. The efficacy, safety and durability of selective renal arterial embolization in treating symptomatic and asymptomatic renal angiomyolipoma. Urology. 2011; 77:642-8. | Article I PubMed

31. Chang YH, Wang LJ, Chuang CK, Wong YC, Wu CT and Hsieh ML. The efficacy and outcomes of urgent superselective transcatheter arterial embolization of patients with ruptured renal angiomyolipomas. J Trauma. 2007; 62:1487-90. | Article | PubMed

32. Sooriakumaran $P$, Gibbs $P$, Coughlin G, Attard V, Elmslie F, Kingswood C, Taylor J, Corbishley C, Patel U and Anderson C. Angiomyolipomata: challenges, solutions, and future prospects based on over 100 cases treated. BJU Int. 2010; 105:101-6. | Article | PubMed

33. Planche O, Correas JM, Mader B, Joly D, Mejean A and Helenon O. Prophylactic embolization of renal angiomyolipomas: evaluation of therapeutic response using CT 3D volume calculation and density histograms. J Vasc Interv Radiol. 2011; 22:1388-95. | Article | PubMed

34. Patatas K, Robinson GJ, Ettles DF and Lakshminarayan R. Patterns of renal angiomyolipoma regression post embolisation on medium- to long-term follow-up. Br J Radiol. 2013; 86:20120633. | Article | PubMed Abstract | PubMed FullText

35. Hocquelet A, Cornelis F, Le Bras Y, Meyer M, Tricaud E, Lasserre AS, Ferriere JM, Robert $G$ and Grenier N. Long-term results of preventive embolization of renal angiomyolipomas: evaluation of predictive factors of volume decrease. Eur Radiol. 2014; 24:1785-93. | Article | PubMed

36. Takebayashi S, Horikawa A, Arai M, Iso S and Noguchi K. Transarterial ethanol ablation for sporadic and non-hemorrhaging angiomyolipoma in the kidney. Eur J Radiol. 2009; 72:139-45. | Article | PubMed

37. Ewalt DH, Diamond N, Rees C, Sparagana SP, Delgado M, Batchelor L and Roach ES. Long-term outcome of transcatheter embolization of renal angiomyolipomas due to tuberous sclerosis complex. J Urol. 2005; 174:1764-6. | Article | PubMed

38. Williams JM, Racadio JM, Johnson ND, Donnelly LF and Bissler JJ. Embolization of renal angiomyolipomata in patients with tuberous sclerosis complex. Am J Kidney Dis. 2006; 47:95-102. | Article | PubMed

39. Lenton J, Kessel D and Watkinson AF. Embolization of renal angiomyolipoma: immediate complications and long-term outcomes. Clin Radiol. 2008; 63:864-70. | Article | PubMed

40. Chick CM, Tan BS, Cheng C, Taneja M, Lo R, Tan YH, Lin SE and Tay KH. Long-term follow-up of the treatment of renal angiomyolipomas after selective arterial embolization with alcohol. BJU Int. 2010; 105:390-4. | Article | PubMed

41. Lee SY, Hsu HH, Chen YC, Huang CC, Wong YC, Wang LJ, Chuang CK and Yang $\mathrm{CW}$. Evaluation of renal function of angiomyolipoma patients after selective transcatheter arterial embolization. Am J Med Sci. 2009; 337:103-8. | Article | PubMed

42. Sauk $S$ and Zuckerman DA. Renal artery embolization. Semin Intervent Radiol. 2011; 28:396-406. | Article | PubMed Abstract | PubMed FullText

43. Jacobson Al, Amukele SA, Marcovich R, Shapiro O, Shetty R, Aldana JP, Lee BR, Smith AD and Siegel DN. Efficacy and morbidity of therapeutic renal embolization in the spectrum of urologic disease. J Endourol. 2003; 17:385-91. | Article | PubMed

44. Ginat DT, Saad WE and Turba UC. Transcatheter renal artery embolization: clinical applications and techniques. Tech Vasc Interv Radiol. 2009; 12:224-39. | Article | PubMed

45. Park JH, Kim WS, Han MC and Lee CW. Renal arterial embolization with absolute ethanol. J Korean Med Sci. 1987; 2:13-8. | PubMed Abstract | PubMed FullText

46. Laurent A. Microspheres and nonspherical particles for embolization. Tech Vasc Interv Radiol. 2007; 10:248-56. | Article | PubMed

47. Massicotte A. Contrast medium-induced nephropathy: strategies for prevention. Pharmacotherapy. 2008; 28:1140-50. | Article | PubMed

48. Brenner DJ and Hall EJ. Computed tomography--an increasing source of radiation exposure. N Engl J Med. 2007; 357:2277-84. | Article I PubMed

49. Smith-Bindman R, Lipson J, Marcus R, Kim KP, Mahesh M, Gould R, Berrington de Gonzalez A and Miglioretti DL. Radiation dose associated with common computed tomography examinations and the associated lifetime attributable risk of cancer. Arch Intern Med. 2009; 169:2078-86. | Article | PubMed Abstract | PubMed FullText

50. Berrington de Gonzalez A, Mahesh M, Kim KP, Bhargavan M, Lewis $\mathrm{R}$, Mettler $\mathrm{F}$ and Land $\mathrm{C}$. Projected cancer risks from computed tomographic scans performed in the United States in 2007. Arch Intern Med. 2009; 169:2071-7. | Article | PubMed

51. Patel SJ, Reede DL, Katz DS, Subramaniam R and Amorosa JK. Imaging the pregnant patient for nonobstetric conditions: algorithms and radiation dose considerations. Radiographics. 2007; 27:1705-22.| Article I PubMed

52. Schwartz MJ, Smith EB, Trost DW and Vaughan ED, Jr. Renal artery embolization: clinical indications and experience from over $\mathbf{1 0 0}$ cases. BJU Int. 2007; 99:881-6. | Article | PubMed

53. Vo NJ, Althoen M, Hippe DS, Prabhu SJ, Valji K and Padia SA. Pediatric abdominal and pelvic trauma: safety and efficacy of arterial embolization. J Vasc Interv Radiol. 2014; 25:215-20. | Article | PubMed

54. van der Vlies $\mathrm{CH}$, Saltzherr TP, Reekers JA, Ponsen KJ, van Delden OM and Goslings JC. Failure rate and complications of angiography and embolization for abdominal and pelvic trauma. J Trauma Acute Care Surg. 2012; 73:1208-12. | Article | PubMed

55. Sam K, Gahide G, Soulez G, Giroux MF, Oliva VL, Perreault P, Bouchard $L$, Gilbert $P$ and Therasse E. Percutaneous embolization of iatrogenic arterial kidney injuries: safety, efficacy, and impact on blood pressure and renal function. J Vasc Interv Radiol. 2011; 22:1563-8. | Article | PubMed

56. Delgado P, Diaz F, Gonzalez A, Hernandez E, Hidalgo R, Hernandez D, Gutierrez $P$ and Lorenzo $V$. Transvascular ethanol embolization: first option for the management of symptomatic nonfunctioning renal allografts left in situ. Transplant Proc. 2003; 35:1684-5. | Article | PubMed

57. Magner $P$ and Bear RA. Renal abscess: complication of ethanol renal devitalization for hypertension in chronic renal failure. CMAJ. 1987; 136:1063-4. | PubMed Abstract | PubMed FullText

58. Atar E, Belenky A, Neuman-Levin M, Yussim A, Bar-Nathan N and Bachar GN. Nonfunctioning renal allograft embolization as an alternative to graft nephrectomy: report on seven years' experience. Cardiovasc Intervent Radiol. 2003; 26:37-9. | Article | PubMed

59. el-Nahas AR, Shokeir AA, Mohsen T, Gad H, el-Assmy AM, el-Diasty $T$ and el-Kappany HA. Functional and morphological effects of postpercutaneous nephrolithotomy superselective renal angiographic embolization. Urology. 2008; 71:408-12. | Article | PubMed

\section{Citation:}

Omodon M, Ayuba G and Patel IJ. Review of renal artery embolization for treatment of renal angiomyolipoma. Clin Nephrol Urol Sci. 2016; 3:1. http://dx.doi.org/10.7243/2054-7161-3-1 